\title{
Determination of Technetium-99 in Environmental Samples by Solvent Extraction at
} Controlled Valence

Chen, Q.J.; Aarkrog, A.; Dick, H.; Mandrup, K.

Publication date:

1987

Document Version

Publisher's PDF, also known as Version of record

Link back to DTU Orbit

Citation (APA):

Chen, Q. J., Aarkrog, A., Dick, H., \& Mandrup, K. (1987). Determination of Technetium-99 in Environmental Samples by Solvent Extraction at Controlled Valence. Risø National Laboratory. Risø-M No. 2671

\section{General rights}

Copyright and moral rights for the publications made accessible in the public portal are retained by the authors and/or other copyright owners and it is a condition of accessing publications that users recognise and abide by the legal requirements associated with these rights.

- Users may download and print one copy of any publication from the public portal for the purpose of private study or research.

- You may not further distribute the material or use it for any profit-making activity or commercial gain

- You may freely distribute the URL identifying the publication in the public portal 


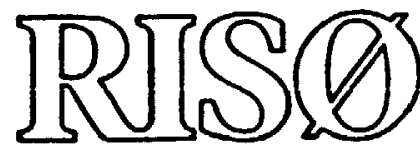 \\ Risø-M-267I \\ Determination of Technetium-99 in Environmental Samples by Solvent Extraction at Controlled Valence}

Qingjiang Chen, A. Aarkrog, Helle Dick, Karen Mandrup

Risø National Laboratory, DK-4000 Roskilde, Denmark October 1987 
RISO-M-2671

DETERMINATION OF TECHNETIUM-99 IN ENVIRONMENTAL SAMPLES BY SOLVENT EXTRACTION AT CONTROLLED VALENCE

Qingjiang Chen, A. aarkrog, Helle Dick, Karen Mandrup

Abstract. Distribution coefficients of technetium and ruthenium are determined under different conditions with $\mathrm{CCl}_{4}$, cyclohexanone, and 58 tri-isooctylanine (TIOA)/xylene. A method for analyzing ${ }^{99}$ Tc in environmental samples has been developed by solvent extraction in which the valences of technetium and ruthenium are controlled with $\mathrm{H}_{2} \mathrm{O}_{2}$ and NaC10. Technetium and ruthenium which are oxidized to $\mathrm{TCO}_{4}^{-}$and $\mathrm{RuO}_{4}^{-}$by $\mathrm{NaClO}^{\circ}$ are separated by extraction with $\mathrm{CCl}_{4}$ at $\mathrm{pH}=4$. The $\mathrm{RuO}_{4}^{-}$is reduced to low valence and technetium is kept in the $\mathrm{TcO}_{4}^{-}$state with $\mathrm{H}_{2} \mathrm{O}_{2}$. Technetium, ruthenium, and other nuclides are subsequently separated by solvent extraction with cyclohexanone and $58 \mathrm{TIOA} / \mathrm{xy}$ lene. The decontamination of the procedure is $1.35 \times 10^{5}$ for ${ }^{103} \mathrm{Ru}$ and $1.66 \times 10^{5}$ for $110 \mathrm{~m}$ Ag. The chemical yield of technetium-99 is 558.

October, 1987

Riso National Laboratory, DK-4000 Roskilde, Denmark 
I8BN 87-550-1368-6

ISSN 0418-6435

Grafisk Service Riso 1987 
CONTENTS

Page

INTRODUCTION.

EXPERIMENTAL . . . . . . . . . . . . . . . . . . . . . . .

PROCEDURE..................................

Principle.............................. 9

Determination of $99 \mathrm{Tc}$ in 501 sea water........... 10

RESULTS AND DISCUSSION.......................... 15

In the solution containing the reducing agent....... 15

In the solution containing the strong oxidizing agent 15

In solution containing gentle oxidizing agent $\mathrm{H}_{2} \mathrm{O}_{2} \ldots 16$

CONCLUSION

REFERENCES

APPENDIX 1

APPENDIX $2 \ldots \ldots \ldots \ldots \ldots \ldots \ldots \ldots \ldots \ldots \ldots \ldots \ldots \ldots \ldots \ldots \ldots \ldots \ldots \ldots \ldots . \ldots \ldots$ 
INTRODUCTION

Technetium-99 $\left(\mathrm{T}_{1 / 2}=2.1 \times 10^{5}\right.$ year $)$ is the daughter product of 99Ho, which is formed by fission of $239 \mathrm{Pu}$ and $235 \mathrm{U}$. Technetium-99 is released to the environment from nuclear power plants, nuclear fuel reprocessing plants, nuclear weapons testing and nuclear medicine. Technetium-99 is expected to be an element important for the collective long-term dose.

Many works have demonstrated that ruthenium tetroxide is quantitatively extracted ${ }^{1}$ by carbon tetrachloride from aqueous solution at $\mathrm{pH}=4$. S. Fot 1 et $\mathbf{a l} .2$ determined technetium in environmental samples with cyclohexanone extraction. N.W. Golchert et al. 3 determined technetium-99 in fresh water with 58 TIOA/ xylene extraction for decontamination. E. Holm et al. 4 determined technetium-99 in environmental samples with tributylphosphate.

After the Chernobyl accident contaminations with ruthenium-103, 106 were found in technetium counting samples of Baltic sea water analysed by tributylphosphate extraction. It was important to develop a new method for ruthenium decontanination from the technetium sample, which can be applied to different types of environmental samples. 
EXPERIMENTAL

1. Determination of the yield of $99 \mathrm{mrc}^{+4}$ by $\mathrm{Fe}(\mathrm{OH})_{2}-\mathrm{Fe}(\mathrm{OH})_{3}$ scavenging

Add $20 \mathrm{ml}$ solution which contains $2 \mathrm{mg} / \mathrm{ml} \mathrm{K}_{2} \mathrm{~S}_{2} \mathrm{O}_{5}$ and $0.16 \mathrm{mg} / \mathrm{ml}$ FeSO $_{4} \cdot 7 \mathrm{H}_{2} \mathrm{O}$. Acidify to $\mathrm{pH}=2$. Add $99 \mathrm{~m}_{\mathrm{Tc}}$ tracer. Shake. Let stand for $30 \mathrm{~min}$. Add $\mathrm{NH}_{4} \mathrm{OH}$ to the solution until $\mathrm{pH}=9$ to get $\mathrm{Pe}(\mathrm{OH})_{2}$ precipitate. Let stand for 2 hours. Filter, r-count on the precipitate and solution to get the yield. The data are shown in table 1. (See appendix 1 ).

2. Determination of the 1088 of $99 \mathrm{mpc}_{\mathrm{Tc}}{ }^{103_{\mathrm{Ru}}}$ by volatilization at $1000^{\circ}$ for different times

To the measuring tube add $20 \mathrm{ml}$ solution which contains $99 \mathrm{~m}$ Tc, 103 Ru tracer, 2 drops ruthenium carrier, $1 \mathrm{ml} 58 \mathrm{NaClO}$ and $1 \mathrm{ml}$ $20 \mathrm{mg} / \mathrm{ml} \mathrm{NaCl}$. $\gamma$-count on original. Then heat the solution in the water bath at $1000 \mathrm{C}$. Measure the count at different times. The data are shown in table 2. (see appendix 1 ).

3. Determination of the chemical yield of $99 \mathrm{mpc}$ by examining the electrodeposition at different times

The solution of $99 \mathrm{~m}$ rc tracer is weighed on the disc which is covered with thin film. Add $20 \mathrm{ml} 2 \mathrm{~N}$ NaOH solution to the electrodeposition cell and add $99 \mathrm{mrc}$ tracer solution which has been weighed. The current is $300 \mathrm{~mA}$. The chemical yields are obtained for different times of electrolysis. The data are shown in table 3. (See appendix 1). 
4. Determination of distribution coefficients of ${ }^{99} \mathrm{mrc}_{\mathrm{r}}{ }^{103_{\mathrm{Ru}}}$ for $\mathrm{CCl}_{4}$ in $58 \mathrm{NaClO}$ at $\mathrm{pH}=4$

Add $0.5 \mathrm{ml} 5 \mathrm{mg} \mathrm{RuCl}_{3} / \mathrm{ml}$, $1 \mathrm{al} \mathrm{N} \mathrm{NaOH,} 2 \mathrm{ml} 58 \mathrm{NaClO}, 99 \mathrm{mrc}$ and ${ }^{103}$ Ru tracer to beaker. Dilute to $10 \mathrm{ml}$. Heat $10 \mathrm{~min}$. to allow isotopic exchange to be completed. Add $3 \mathrm{~N}_{2} \mathrm{SO}_{4}$ one drop at a time with swirling until the greenish mixture suddenly turns yellow, indicating the formation of ruthenium tetroxide (RuO4) from perruthenate. This will occur at pH=4. Extract with $10 \mathrm{ml} \mathrm{CCl} 4$. Shake 10 seconds. The data are shown in table 4 (See appendix 1).

The extraction rate of RuO $_{4}$ depends on the purification of $\mathrm{CCl}_{4}$, appropriate carrier of Ru and extraction shaking time. Because the $\mathrm{RuO}_{4}$ is reduced by an impurity organic agent, the longer the shaking time, the more $\mathrm{RuO}_{4}$ is reduced. The greater the impurity organic agent in the $\mathrm{CCl}_{4}$, the more $\mathrm{RuO}_{4}$ is reduced. The less the amount of carrier of $\mathrm{Ru}$, the higher the per cent of RuO 4 that is reduced.

5. Determination of distribution coefficient of 99mic for cyclohexanone extraction in different $\mathrm{H}_{2} \mathrm{SO}_{4}$ concentrations

Add $99 \mathrm{mrc}$ and 3 drops 58 Nac10 to the beaker to get $\mathrm{TCO}_{4}^{-}$. Dilute to $10 \mathrm{ml}$ with different concentrations of $\mathrm{H}_{2} \mathrm{SO}_{4}$. Extract with $10 \mathrm{ml}$ cyclohexanone. Shake $1 \mathrm{~min}$. $\gamma$-count the organic and aqueous phases. The data are shown in table 5. (See appendix 1 ).

6. Determination of the distribution coefficient of $99 \mathrm{mrc}$ for different concentrations of sulphuric acid with 58 TIOA/ xylene

Add $99 \mathrm{~m}_{\mathrm{Tc}}$ tracer and a few drops $308 \mathrm{H}_{2} \mathrm{O}_{2}$ to 5 ml solution to get $\mathrm{TCO}_{4}^{-}$. Extract with $5 \mathrm{ml} 58$ TIOA/xylene in different concentrations of sulphuric acid. Shake 1 min. The data are shown in table 6. (See appendix 1 ). 
7. Determination of the distribution coefficient of 99mp and ${ }^{103} \mathrm{Ru}$ with $58 \mathrm{TIOA} / x y l e n e$ and cyclohexanone in $2 \mathrm{~N} \mathrm{H}_{2} \mathrm{SO}_{4}-$ $\mathrm{R}_{2} \mathrm{~S}_{2} \mathrm{O}_{5}$

Add $10 \mathrm{ml}$ solution to the separation funnel which contains about $2 \mathrm{mg} / \mathrm{ml} \mathrm{K}_{2} \mathrm{~S}_{2} \mathrm{O}_{5}$ and $99 \mathrm{~m}$ Tc tracer. At $\mathrm{pH}=2$, let stand for $20 \mathrm{~min}$. to get Tct4: Extract with $58 \mathrm{TIOA} / x y$ lene and cyclohexanone. $V_{\text {org.: }} \mathrm{V}_{\text {aqu. }}=10: 10 \mathrm{ml}$. Shake for $1 \mathrm{~min}$. $r$-measure the organic and aqueous phases. The data are shown in table 7. (See appendix 1 ).

8. Determination of the distribution coefficient of $99 \mathrm{mpc}$ and ${ }^{103} \mathrm{Ru}$ in $1 \mathrm{~N} \mathrm{H} \mathrm{SO}_{4}-\mathrm{H}_{2} \mathrm{O}_{2}$ with $58 \mathrm{TIOA} / \mathrm{xy}$ lene and cyclohexanone

Add $1 \mathrm{ml} 5 \mathrm{~N}$ NaOH, $99 \mathrm{mTc},{ }^{103} \mathrm{Ru}$ tracer and $2 \mathrm{ml} 58$ Naclo to the beaker. Heat for $10 \mathrm{~min}$. Technetium and ruthenium are oxidized to $\mathrm{TCO}_{4}^{-}, \mathrm{RuO}_{4}^{-}$. Then add $1 \mathrm{ml} 308 \mathrm{H}_{2} \mathrm{O}_{2}$ to the solution. The $\mathrm{RuO}_{4}$ is reduced to low valence. Technetium is kept in $\mathrm{TCO}_{4}^{-}$ state. Dilute to $10 \mathrm{ml}$. Acidify the solution to $1 \mathrm{~N} \mathrm{H}_{2} \mathrm{SO}_{4}$. Exract with $10 \mathrm{ml} 5 \mathrm{TIOA} / \mathrm{xy}$ lene and cyclohexanone. The data are shown in table 8 . (See appendix 1 ).

9. Determination of the distribution coefficient of $99 \mathrm{~m}_{\mathrm{Tc}}$ and ${ }^{103} \mathrm{Ru}$ in $2 \mathrm{~N} \mathrm{H}_{2} \mathrm{SO}_{4}-58 \mathrm{NaClO}$ extraction with $58 \mathrm{TIOA} / x y l e n e$ and cyclohexanone

Add $1 \mathrm{ml} 5 \mathrm{~N}$ NaOH, $1 \mathrm{ml} 58 \mathrm{NaClO}, 99 \mathrm{mp}, 103_{\mathrm{Ru}}$ tracer and ruthenium carrier to beaker. Heat $10 \mathrm{~min}$. to allow isotopic exchange to be completed. Acidify to $2 \mathrm{~N} \mathrm{H}_{2} \mathrm{SO}_{4}$ and dilute to $10 \mathrm{ml}$. Extract with $10 \mathrm{ml}$ cyclohexanone and $58 \mathrm{TIOA} / x y l e n e$. The data are shown in table 9. (See appendix 1 ).

10. Determination of back-extraction rate of 99 mic from cyclohexanone with $\mathrm{H}_{2} \mathrm{O}$ and $0.5 \mathrm{~N}$ NaOH

Add $10 \mathrm{ml}$ cyclohexanone into which 99mTc is extracted and $10 \mathrm{ml}$ cyclohexanone to a separator funnel. Back-extract with $10 \mathrm{ml} \mathrm{H} \mathrm{H}_{2} \mathrm{O}$ and $0.5 \mathrm{~N}$ NaOH, respectively- Compare the back-extraction rate shown in table 10. (See appendix 1 ). 
11. Determination of back-extraction rate of 99 mpc from 58 TIOA/ xylene with $2 \mathrm{~N}$ NaOH

Add $10 \mathrm{ml} 58 \mathrm{TIOA} / x y$ lene into which the 99mpc is extracted and $10 \mathrm{ml} 2 \mathrm{~N}$ NaOH. Shake $2 \mathrm{~min}$. Measure the count of organic and aqueous phases. The data are shown in table 11. (See appendix 1).

PROCEDURE

\section{Principle}

The high scavenging rate of $99 \mathrm{mpc}^{+4}$ is shown in table 1 by $\mathrm{Pe}(\mathrm{OH})_{2}-\mathrm{Pe}(\mathrm{OH})_{3}$. The $\mathrm{Pe}(\mathrm{OH})_{2}-\mathrm{Pe}(\mathrm{OH})_{3}$ is dissolved in $\mathrm{H}_{2} \mathrm{SO}_{4}$ Add $58 \mathrm{NaClO}$ to get $\mathrm{TCO}_{4}^{-}$and $\mathrm{RuO}_{4}^{-}$. Heat the solution. The RuO is volatilized and the $\mathrm{TCO}_{4}^{-}$left in solution, as shown in table 2. This is the first step for separating the technetium and ruthenium.

The second step is oxidation of the technetium and ruthenium to RuO $_{4}^{-}$and $\mathrm{TCO}_{4}^{-}$with $58 \mathrm{NaC10}$. At $\mathrm{pH}=4$, the RuO 4 is extracted by $\mathrm{CCl}_{4}$. The $\mathrm{TCO}_{4}^{-}$is left in the solution, as shown in table 4.

The third step for decontaminating ruthenium and other nuclides is reduction of the $\mathrm{RuO}_{4}$ to a $10 \mathrm{w}$ valence state and maintenance of technetium at the $\mathrm{TCO}_{4}^{-}$state with $308 \mathrm{H}_{2} \mathrm{O}_{2}$. The $\mathrm{TCO}_{4}^{-}$is extracted with cyclohexanone, and ruthenium is left in the solution, as shown in table 8 .

The fourth step decontaminating ruthenium and other nuclides is extraction of the $\mathrm{TCO}_{4}^{-}$and leaving the ruthenium in $1 \mathrm{~N}_{2} \mathrm{SO}_{4}-$ $308 \mathrm{H}_{2} \mathrm{O}_{2}$ by $58 \mathrm{TIOA} / x y$ lene extraction. scavenging Pe(OH) 3 and AgCl precipitate are used for decontamination. 
The procedure follows in detail:

\section{Determination of ${ }^{99} \mathrm{TC}$ in $50 \mathrm{~L}$ sea water}

1. Acidify the $50 \mathrm{~L}$ sea water to $\mathrm{pH}=2-2.5$ with concentrated $\mathrm{BCl}$.

2. Add $99 \mathrm{~m}_{\mathrm{Tc}}, 110 \mathrm{~m}_{\mathrm{Ag}},{ }^{103} \mathrm{Ru}, 1 \mathrm{ml} 5 \mathrm{mg} / \mathrm{ml}$ ruthenium carrier to 50 L sea water.

3. Add $100 \mathrm{~g} \mathrm{~K}_{2} \mathrm{~S}_{2} \mathrm{O}_{5} \mathrm{mix}$. Leave for 20-30 min. to get the $\mathrm{Tc}^{+4}$ state.

4. Add $7.4 \mathrm{~g} \mathrm{FeSO}_{4} \cdot 7 \mathrm{H}_{2} \mathrm{O} \mathrm{mix}$. Leave for $5 \mathrm{~min}$.

5. Add $\mathrm{NH}_{4} \mathrm{OH}$ (about $140 \mathrm{ml}$ concentrated $\mathrm{NH}_{4} \mathrm{OH}$ ) to the sea water till a precipitate is observed. Stand overnight. Centrifuge.

6. Dissolve the $\mathrm{Pe}(\mathrm{OH})_{2}$ with $10 \mathrm{ml} 10 \times \mathrm{H}_{2} \mathrm{SO}_{4}$. Heat $5 \mathrm{~min}$. to dissolve $\mathrm{Fe}(\mathrm{OH})_{2}$. Dilute to $150 \mathrm{ml}$. Add $10 \mathrm{ml} 15 \mathrm{NaClO}$. Heat $10 \mathrm{~min}$. to get $\mathrm{TCO}_{4}^{-}$and $\mathrm{RuO}_{4}^{-}$. Add $\mathrm{NaOH}$ (about $26 \mathrm{ml}$ $5 \mathrm{~N} \mathrm{NaOH}$ ) to get $\mathrm{Pe}(\mathrm{OH}) 3 \mathrm{pH}=12$. Heat the solution to a large precipitate. The $\mathrm{RuO}_{4}^{-}$is volatilized. Centrifuge. Pilter. Add $10 \mathrm{ml} 10 \mathrm{~N} \mathrm{~B}_{2} \mathrm{SO}_{4}$ to dissolve the $\mathrm{Fe}(\mathrm{OH}) 3$. Heat for $5 \mathrm{~min}$. Add $5 \mathrm{ml} 158 \mathrm{Naclo}$. Dilute to $150 \mathrm{ml}$. Heat for $10 \mathrm{~min}$. Add $26 \mathrm{ml} 5 \mathrm{~N} \mathrm{NaOH}$ to $\mathrm{pH}=12$ to get $\mathrm{Pe}(\mathrm{OH})_{3}$. Heat the solution. Centrifuge. Pilter. Combine these solutions. Discard the $\mathrm{Pe}(\mathrm{OH})_{3}$.

7. Add $2 \mathrm{ml} 58 \mathrm{NaClO}$. Evaporate to $80 \mathrm{ml}$. Add $2 \mathrm{ml} 58 \mathrm{NaClO}$. Heat for $10 \mathrm{~min}$. Acidify to $\mathrm{pH}=4$ to get a yellow colour with $3 \mathrm{~N} \mathrm{H}_{2} \mathrm{SO}_{4}$.

8. Extract with $40 \mathrm{ml} \mathrm{CCl} 4$ (two times). Discard the $\mathrm{CCl}_{4}$. 
9. Add $2 \mathrm{ml} 1 \mathrm{~N}$ NaOH, $2 \mathrm{ml} 5$ NaClo and Ru carrier $0.5 \mathrm{ml} 5$ $\mathrm{mg} / \mathrm{ml} \mathrm{RuCl} 3$. Heat for $10 \mathrm{~min}$. Stir. Acidify to $\mathrm{pH}=4$ with $\mathrm{H}_{2} \mathrm{SO}_{4}$. Extract two times with $\mathrm{CCl}_{4}$. Shake for 15 seconds. The $\mathrm{RuO}_{4}$ is extracted into $\mathrm{CCl}_{4} \cdot \mathrm{TCO}_{4}^{-}$is left in an aqueous solution.

10. Acidify the aqueous solution to $1 \mathrm{~N} \mathrm{HCl}$ and $1 \mathrm{~N} \mathrm{H}_{2} \mathrm{SO}_{4}$. $(80 \mathrm{ml})$. Add $1 \mathrm{ml} 308 \mathrm{H}_{2} \mathrm{O}_{2}$. Heat for $10 \mathrm{~min}$.

11. Add $60 \mathrm{ml}$ cyclohexanone and the solution to separator funnel. Shake for $5 \mathrm{~min}$. Stand for $5 \mathrm{~min}$. Wash with $60 \mathrm{ml}$ $2 \mathrm{~N} \mathrm{H}_{2} \mathrm{SO}_{4}$ containing a few drops $308 \mathrm{H}_{2} \mathrm{O}_{2}$. Discard the aqueous phase.

12. Add $80 \mathrm{ml}$ cyclohexane and $30 \mathrm{ml} \mathrm{H}_{2} \mathrm{O}$. Back-extract three times, each time with $30 \mathrm{ml} \mathrm{H}_{2} \mathrm{O}$.

13. Add $1 \mathrm{ml} 10 \mathrm{mg} / \mathrm{ml} \mathrm{AgNO}_{3}$. Heat for $10 \mathrm{~min}$. Add $2 \mathrm{ml} 58 \mathrm{NaClO}$ and $2 \mathrm{ml} \mathrm{NaCl} 20 \mathrm{mg} / \mathrm{ml}$ to get a precipitate. Heat for 20 min. Filter.

14. Repeat step 13.

15. Acidify to $1 \mathrm{~N} \mathrm{H}_{2} \mathrm{SO}_{4}$. Evaporate to $30 \mathrm{ml}$. Add $1 \mathrm{ml} 308$ $\mathrm{H}_{2} \mathrm{O}_{2}$. Heat for $10 \mathrm{~min}$.

16. Extract with $25 \mathrm{ml} 58 \mathrm{TIOA} / x y$ lene. Shake for $2 \mathrm{~min}$. Wash with $25 \mathrm{ml} 1 \mathrm{~N} \mathrm{H}_{2} \mathrm{SO}_{4}$ containing a few drops $308 \mathrm{H}_{2} \mathrm{O}_{2}$. Shake for $2 \mathrm{~min}$.

17. Back-extract two times, each time with $20 \mathrm{ml} 1 \mathrm{~N} \mathrm{NaOH}$.

18. Evaporate to $20 \mathrm{ml}$ for electrodeposition. The current is $300 \mathrm{~mA}$. The time is 3 to 5 hours.

19. The results are shown in table 12 . 
Flow sheet

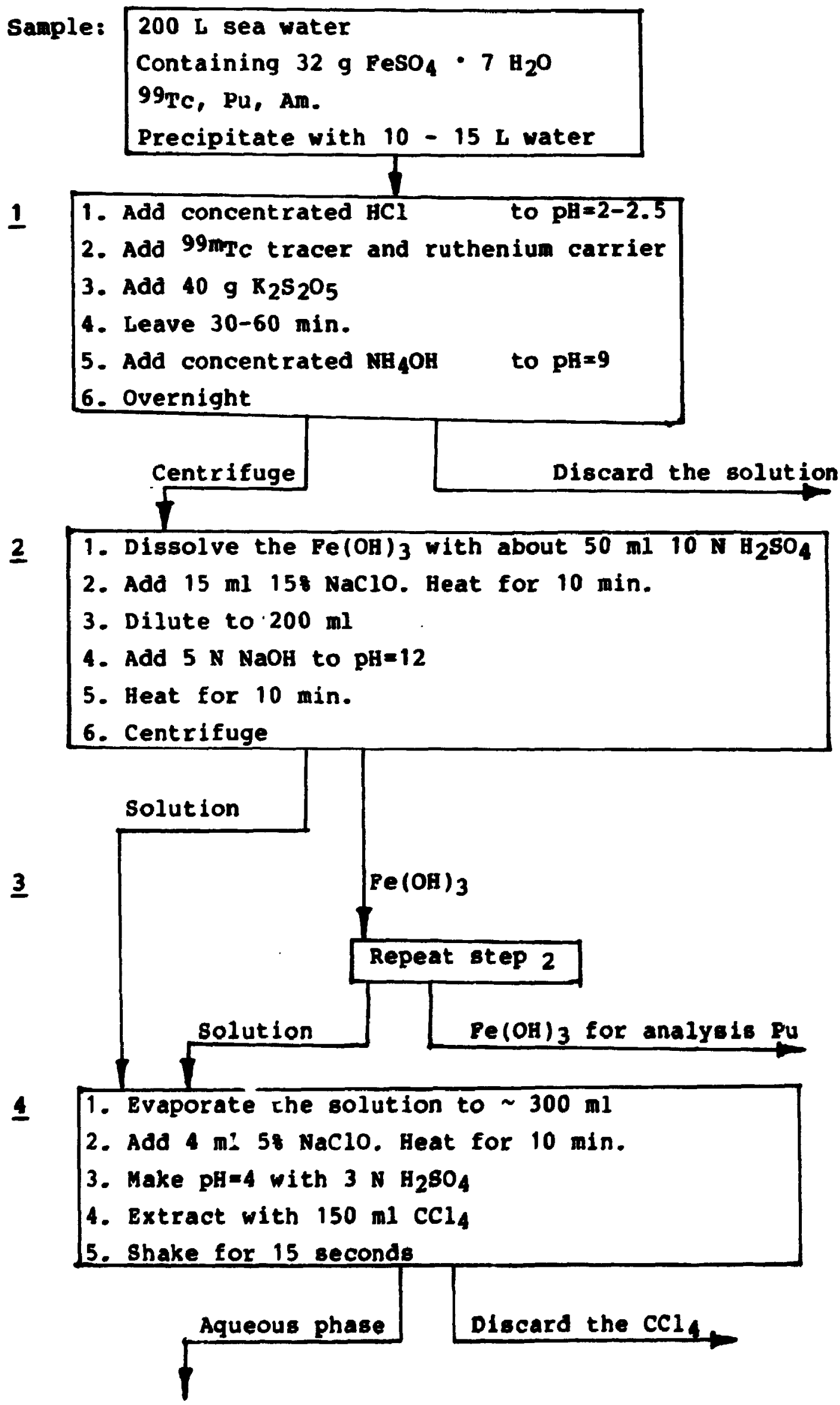


$5\left[\begin{array}{l}\text { 1. Add } 2 \mathrm{ml} 5 \mathrm{~N} \mathrm{NaOH,} 8 \mathrm{ml} 158 \mathrm{NaClO} \text { and a few drops } \mathrm{RuCl}_{3} \\ \text { 2. Heat for } 10 \mathrm{~min} . \\ \text { 3. Make } \mathrm{pH}=4 \text { with } 3 \mathrm{~N} \mathrm{H}_{2} \mathrm{SO}_{4} \\ \text { 4. Bxtract with } 150 \mathrm{ml} \mathrm{CCl} 4 \\ \text { 5. Shake for } 15 \text { seconds }\end{array}\right.$

1. Acidify the solution to $1 \mathrm{~N} \mathrm{HCl}+1 \mathrm{~N} \mathrm{H}_{2} \mathrm{SO}_{4}$

2. Add $2 \mathrm{ml} 30$ : $\mathrm{H}_{2} \mathrm{O}_{2}$ - Shake.

3. Extract with $150 \mathrm{ml}$ cyclohexanone. Shake $5 \mathrm{~min}$. Leave $10 \mathrm{~min}$.

1. Wash with $150 \mathrm{ml} 2 \mathrm{~N} \mathrm{H}_{2} \mathrm{SO}_{4}$ containing $0.2 \mathrm{ml} 308 \mathrm{H}_{2} \mathrm{O}_{2}$

2. Shake for $5 \mathrm{~min}$.

3. Stand for $5 \mathrm{~min}$.

I 1. Back-extrast with $150 \mathrm{ml}$ cyclohexane and $80 \mathrm{ml} 0.5$ N $\mathrm{NaOH}$

2. Shake for $5 \mathrm{~min}$. Stand for $5 \mathrm{~min}$.

8

Aqueous phase $\quad$ Organic phase

21 . Add $4 \mathrm{ml} 5 \% \mathrm{NaC} 10$

2. Add $0.5 \mathrm{ml} 20 \mathrm{mg}$ AgNO $_{3} / \mathrm{ml}$

3. Heat for $15 \mathrm{~min}$.

A. P11ter 
10 1. Acidify the solution to $1 \mathrm{~N} \mathrm{H}_{2} \mathrm{SO}_{4}$

2. Add $2 \mathrm{ml} 30$ : $\mathrm{H}_{2} \mathrm{O}_{2}$

3. Evaporate the solution to $50 \mathrm{ml}$

4. Bxtract with $30 \mathrm{ml} 58 \mathrm{TIOA} / \mathrm{xy}$ lene

5. Shake for $5 \mathrm{~min}$.

Organic phase

Discard the aqueous phase

11 1. Wash with $40 \mathrm{ml} 1 \mathrm{~N} \mathrm{H}_{2} \mathrm{SO}_{4}$ containing $0.2 \mathrm{ml} 30 \% \mathrm{H}_{2} \mathrm{O}_{2}$ shake for 2 min.

12 1. Back-extract with $20 \mathrm{ml} 1 \mathrm{~N}$ NaOH

2. Shake for 2 min.

Organic phase Discard the aqueous phase 
RESULTS AND DISCUSSION

The volatilization rates of $\mathrm{RuO}_{4}^{-}$and $\mathrm{TCO}_{4}^{-}$are determined by $100^{\circ} \mathrm{C}$ in $1 \mathrm{~N} \mathrm{~B}_{2} \mathrm{SO}_{4}-\mathrm{NaClO}$ solution; 998 of $\mathrm{RuO}_{4}^{-}$is volatilized in 30 minutes, while $\mathrm{TCO}_{4}^{-}$is left in the solution. No volatilisation of $\mathrm{TCO}_{4}^{-}$was found by heating for hours at $100^{\circ} \mathrm{C}$.

The method of $\mathrm{CCl}_{4}$ solvent extraction is applied in the determination of ruthenium. It is applied in the present work for ruthenium decontamination. The extraction rates of $\mathrm{RuO}_{4}$ and $\mathrm{TCO}_{4}^{-}$ are shown in table 4. The $\mathrm{RuO}_{4}$ is extracted by $\mathrm{CCl}_{4}$ at $\mathrm{pH}=4$ in Nac10 solution, and the $\mathrm{TCO}_{4}^{-}$is left in solution. The distribution coefficient of $99 \mathrm{mpc}$ depends on the concentration of su1phuric acid in $58 \mathrm{TICA} / \mathrm{xy}$ lene and cyclohexanone. The extraction rate is more than 998 from $0.2 \mathrm{~N} \mathrm{~B}_{2} \mathrm{SO}_{4}$ to $4 \mathrm{NB}_{2} \mathrm{SO}_{4}$.

In the solution containing the reducing agent

In the $\mathrm{K}_{2} \mathrm{~S}_{2} \mathrm{O}_{5}-\mathrm{HCl}$ solution at $\mathrm{pH}=2$, technetiun is reduced to $\mathrm{Tc}^{+4}$, and ruthenium to a low valence state. Acidify to $2 \mathrm{~N}_{2} \mathrm{SO}_{4}$ The extraction rates of technetium and ruthenium are obtained by cyclohexanone and $58 \mathrm{TIOA} / x y$ lene, as shown in table 7.

In the solution containing the strong oxidizing agent

Technetium and ruthenium are oxidized to $\mathrm{RuO}_{4}^{-}$and $\mathrm{TCO}_{4}^{-}$in a strong oxidizing agent. The extraction rate of $99 \mathrm{mc}$ and $103_{\mathrm{Ru}}$ are obtained in $2 \mathrm{~N} \mathrm{H}_{2} \mathrm{SO}_{4}$ - $\mathrm{MaClO}$ with cyclohexanone, $58 \mathrm{TIOA}$ xylene, as shown table 9. If technetium and ruthenium are held in a $\mathrm{TCO}_{4}^{-} / \mathrm{RuO}_{4}^{-}$state, the technetium and ruthenium cannot be separated by extraction with cyclohexanone and $58 \mathrm{TIOA} / \mathrm{xy}$ lene in $2 \mathrm{~N}_{2} \mathrm{SO}_{4}-\mathrm{NaClO}$. 
In solution containing gentle oxidizing agent $\mathrm{H}_{2}{ }_{2} 2$

The technetiun is oxidized $\mathrm{LO}_{\mathrm{TcO}}^{-}$, and rutheniun is kept in a low valence state. The extraction rates are shown in table 8. The ruthenium and technetium can be separated by extraction with cyclohexanone and $58 \mathrm{TIOA} / x y l e n e$ in $1 \mathrm{~N}_{2} \mathrm{SO}_{4}-\mathrm{H}_{2} \mathrm{O}_{2}$.

The different valence states of technetium and ruthenium are controlled with $\mathrm{H}_{2} \mathrm{O}_{2}$ and $\mathrm{NaClO}$ in different steps in the procedure to get a higher rutheniun decontanination. The decontanination factors of ruthenium for each step in the procedure are shown as follows:

Step Decontamination factor of ruthenium

Heating at $100{ }^{\circ} \mathrm{C}$

$1 \mathrm{~N} \mathrm{H}_{2} \mathrm{SO}_{4}-\mathrm{NaClO} \quad 110$

$\mathrm{CCl}_{4}$ extraction $\quad 600$

Cyclohexanone extraction 230

5* TIOA/xylene extraction 250

According to the step-by-step decontamination of the procedure, the decontamination factor for ruthenium should be $3.5 \times 10^{9}$. But the large volume sea water is more complicated, as it contains many elements. Add the low count of $103_{R u}$ for the decontamination test, so that the decontamination of the procedure is only $1.35 \times 10^{5}$ for $103 \mathrm{Ru}$ and $1.66 \times 10^{5}$ for $110 \mathrm{~m}$.

Technetium is lost in each step of the procedure as follows:

step

Lose in Pe(OH) 2 carried

$\mathrm{CCl}_{4}$ extraction

Pe(OH) 3 scavenging

AgCl precipitate

Cyclohexanone extraction

5irIOA/xylene extracticn

Electrodeposition

\section{Lose rate of 99 mpe}

$\sim 5$

$\sim 5$

$\sim 10$

$\sim 10$

$\sim 5$

$\sim 5$

$\sim 5$

The chemical yield of the procedure is about 55 percent. 
CONCLUSION

1. Ruthenium is volatilized; however, no volatilization of tech-

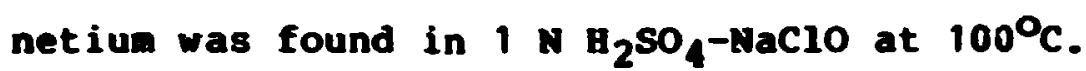

2. Ruthenium and technetium can be separated to permit the extraction of $\mathrm{RuO}_{4}$, and the $\mathrm{TCO}_{4}^{-}$is kept in solution at $\mathrm{pH}=4$ containing NaClo with $\mathrm{CCl}_{4}$.

3. Both the RuO and $58 \mathrm{TIOA} / x y$ lene in $1 \mathrm{~N} \mathrm{H}_{2} \mathrm{SO}_{4}$ solution in which the valences are controlled with Naclo. Therefore, the ruthenium and technetiun cannot be separated in this way.

4. Rutheniun cannot be extracted but technetiun can be by cyclohexanone and 5 s TOA/xylene in which the rutheniun is reduced to low valence and the technetiun is kept in $\mathrm{TcO}_{4}^{-}$ state at a controlled valence with $\mathrm{H}_{2} \mathrm{O}_{2}$. This permits separation of the rutheniun and technetium.

5. Fe(OH) 3 scavenging, extraction of cyclohexanone and 5 , TIOA/ xylene are used for decontamination of ruthenium and other nuclides. The $1.35 \times 105$ of ruthenium-103 and $1.66 \times 105$ $110 \mathrm{mig}$ decontanination factor are obtained.

7. The procedure can be applied to different types of environmental samples, and the average chemical yield for Tc is about 608 . 
REPERBNCES

1. Jesse W.T. Meadows et al. Anal. Chem., 22, 1277 (1950).

2. S. Poti et al. Anal. Chim. Acta, 60, 269 (1972).

3. H.w. Golchert et al. Anal Chem., 41, 669 (1969).

4. E. Bolm et al. Nuclear Instrument and Methods in Physics Research 223 (1984) 204-207. 


\section{APPENDIX 1}

Table 1. Yield of $99 m_{\mathrm{Tc}}$ by $\mathrm{Fe}(\mathrm{CH})_{2}-\mathrm{Fe}(\mathrm{OB})_{3}$

$\begin{array}{cccc}\text { Mo. } & \begin{array}{c}\text { Precipitate count } \\ \text { C.P.S. }\end{array} & \begin{array}{c}\text { Solution Count } \\ \text { C.P.S. }\end{array} & \text { Yield } \\ 1 & 2632.2 & 90.2 & 96.7 \\ 2 & 2500.2 & 107.6 & 95.9 \\ 3 & 2506.1 & 101.0 & 96.1\end{array}$




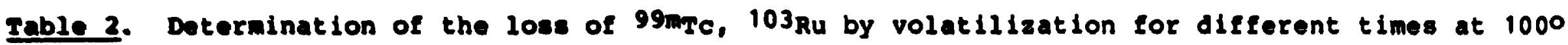

\begin{tabular}{|c|c|c|c|c|c|c|c|c|c|c|c|}
\hline $\begin{array}{l}\text { Composition } \\
\text { of solution }\end{array}$ & No. & Nucl 1dea & $\begin{array}{l}\text { Timo } \\
(\min .)\end{array}$ & 5 & 10 & 20 & 30 & 60 & 90 & 120 & 240 \\
\hline $\begin{array}{l}1 \mathrm{ml} \mathrm{H}_{2} \mathrm{SO}_{4}, 1 \mathrm{ml} \\
58 \mathrm{NaClO}, 1 \mathrm{ml} \\
20 \mathrm{mg} / \mathrm{ml} \mathrm{NaCl} \\
2 \text { drope Ru carrier, } \\
7 \mathrm{ml} \mathrm{H}_{2} \mathrm{O}\end{array}$ & 2 & $\begin{array}{c}99 \mathrm{mpc}_{\mathrm{Tc}} \\
103_{\mathrm{Ru}} \\
99 \mathrm{mmc}_{\mathrm{rc}} \\
103_{\mathrm{Ru}}\end{array}$ & Loss 1 & $\begin{array}{l}- \\
72 \\
2.9 \\
59.6\end{array}$ & $\begin{array}{r}0.6 \\
90.2 \\
4.9 \\
89.1\end{array}$ & $\begin{array}{r}2.6 \\
95.5 \\
3.6 \\
95.5\end{array}$ & $\begin{array}{r}1.8 \\
99.2 \\
3.1 \\
99.1\end{array}$ & & $\begin{array}{r}7.1 \\
99.4 \\
4.6 \\
99.4\end{array}$ & & \\
\hline $\begin{array}{l}1 \mathrm{~B}_{2} \mathrm{SO} \\
(10 \mathrm{ml})\end{array}$ & $\begin{array}{l}1 \\
2\end{array}$ & $\begin{array}{l}99 \text { mise } \\
99 \text { mire }\end{array}$ & & & & & & $\begin{array}{l}0 \\
0\end{array}$ & & $\begin{array}{l}2.5 \\
2.3\end{array}$ & $\begin{array}{l}0 \\
0\end{array}$ \\
\hline $\begin{array}{l}10 \mathrm{ml} \mathrm{N} \mathrm{B}_{2} \mathrm{SO}_{4} \\
2 \mathrm{mg} / \mathrm{ml} \mathrm{NaCl} \\
0.5 \mathrm{NaClO}\end{array}$ & $\begin{array}{l}1 \\
2\end{array}$ & $\begin{array}{l}\text { 99mec } \\
\text { 99mic }\end{array}$ & & & & & & $\begin{array}{l}0 \\
0\end{array}$ & & $\begin{array}{l}0 \\
0\end{array}$ & $\begin{array}{l}0 \\
0\end{array}$ \\
\hline
\end{tabular}


Table 3. Chemical yield of 99me electrodeposition for different times

Tine (min.) 33

66

96

180

240

300

Chen. yield

$\begin{array}{lllllll}38.3 & 65.8 & 85.3 & 92.5 & 93.4 & 95.3\end{array}$

Table 4. Distribution coefficients for extraction of 99me,

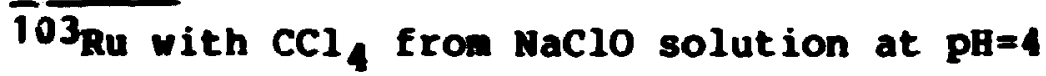

Muclides No. Org.phase Aqu.phase Distribution Extraction

C.P.S.

C.P.S. coefficient

rate 8

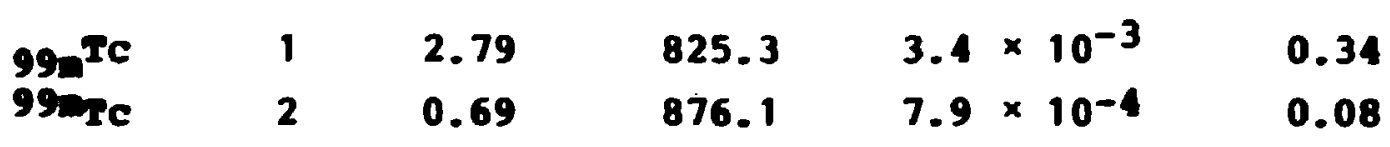

$\begin{array}{llllll}103_{\mathrm{Ru}} & 1 & 245.2 & 3.35 & 73.3 & 98.7 \\ 103_{\mathrm{Ru}} & 2 & 364.0 & 5.42 & 67.2 & 98.5 \\ 103_{\mathrm{Ru}} & 3 & 167.2 & 2.06 & 81.3 & 98.8 \\ 103_{\mathrm{Ru}} & 4 & 169.7 & 1.54 & 110.4 & 99.1\end{array}$

$83.0+19$

(average) 
Table 5. Distribution coefficient of 99 mp related to sulphuric acid concentration in cyclohexanone

Concentration Org.phase Aqu.phase Distribution Extraction of $\mathrm{B}_{2} \mathrm{SO}_{4}$ C.P.S. coefficient rate $\$$

$0.2 \mathrm{H} \mathrm{H}_{2} \mathrm{SO}_{4}$ 3562.9

43.6

81.8

98.79

0.5

5210.6

44.5

117.1

99.15

1.0

4988.2

43.9

113.6

99.13

2.0

4682.7

31.2

149.9

99.34

3.0

4687.4

25.4

184.6

99.46

4.0

4392.9

22.0

199.1

99.50

Table 6. Distribution coefficient of 99me dependence on sulphuric acid in 58 TIOA/xylene

Concentration Org.phase Agu.phase Distribution Extraction of $\mathrm{H}_{2} \mathrm{SO}_{4}$

C.P.S. C.P.S. coefficient rate 8

$0.2 \mathrm{~N} \mathrm{~B}_{2} \mathrm{SO}_{4}$
0.5
1.0
2.0
3.0
4.0

3668.5
4669.3
4374.0
2500.0
3782.8
4036

5.77

635.8

99.84

4.0

4036

1.00

4667

99.98

1.33

3288.7

99.97

0.84

2659

99.96

1.36

2781

99.96

2.53

1595

99.93 
Table 7. Determination of distribution coefficient of 99mc and ${ }^{103} \mathrm{Ru}$ for $2 \mathrm{~N} \mathrm{H}_{2} \mathrm{SO}_{4}-\mathrm{R}_{2} \mathrm{~S}_{2} \mathrm{O}_{5}$ with either a) TrOA/xylene or b) Cyclohexanone

Iuclides No. Org.phase Aqu.phase Distribution Extraction C.P.S. C.P.S. coefficient rate 8

a) 5 TIOA/xylene - $1 \mathrm{~N} \mathrm{H} \mathrm{SO}_{4}-\mathrm{R}_{2} \mathrm{~S}_{2} \mathrm{O}_{5}$

$\begin{array}{llllll}99 \text { re } & 1 & 2018.9 & 192.5 & 10.5 & 91.3 \\ 99 \text { re } & 2 & 1883.8 & 152.6 & 12.3 & 92.5\end{array}$

$\begin{array}{llllll}103_{\text {Ru }} & 1 & 2.62 & 388.75 & 6.7 \times 10^{-3} & 0.67 \\ 103_{\text {Ru }} & 2 & 1.82 & 280.55 & 6.5 \times 10^{-3} & 0.64\end{array}$

b) Cyclohexanone - $2 \mathrm{NH}_{2} \mathrm{SO}_{4}-\mathrm{K}_{2} \mathrm{~S}_{2} \mathrm{O}_{5}$

$\begin{array}{llllll}99 \text { mec } & 1 & 1119.35 & 138.27 & 8.1 & 89.0 \\ 99 \text { mec } & 2 & 1225.28 & 127.70 & 9.6 & 90.6\end{array}$

$\begin{array}{lllllll}103_{\mathrm{Ru}} & 1 & 8.197 & 319.45 & 2.6 \times 10^{-2} & 2.5 \\ { }_{103_{\mathrm{Ru}}} & 2 & 8.347 & 293.89 & 2.8 \times 10^{-2} & 2.76\end{array}$




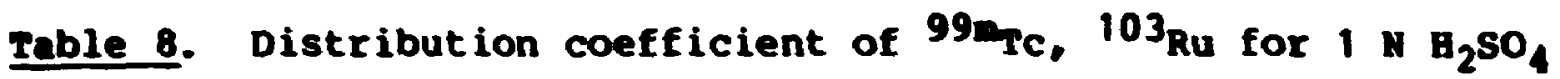
$-\mathrm{H}_{20} \mathrm{O}_{2}$ with 5 TIOA/xylene and cyclohexanone

Muclides No. Org.phase Aqu.phase Distribution Extraction

C.P.S C.P.S. coefficient rate

a) Cyclohexanone - $\mathrm{H}_{2} \mathrm{O}_{2}-1 \mathrm{NH}_{2} \mathrm{SO}_{4}$

$\begin{array}{llllll}990 \text { Tc } & 1 & 5024.91 & 16.44 & 305.7 & 99.7 \\ 990 \text { Tc } & 2 & 4666.31 & 11.87 & 393.7 & 99.7\end{array}$

$\begin{array}{llllll}103_{\mathrm{Ru}} & 1 & 0.147 & 288.87 & 5.0 \times 10^{-4} & 0.05 \\ 103_{\mathrm{Ru}} & 2 & 2.762 & 142.36 & 6.2 \times 10^{-3} & 0.62 \\ 103_{\mathrm{Ru}} & 3 & 1.327 & 320.25 & 4.1 \times 10^{-3} & 0.41 \\ 103_{\mathrm{Ru}} & 4 & 2.027 & 327.65 & 6.2 \times 10^{-3} & 0.62\end{array}$

b) $58 \mathrm{TIOA} /$ xylene $-1 \mathrm{~N} \mathrm{H}_{2} \mathrm{SO}_{4}-\mathrm{H}_{2} \mathrm{O}_{2}$

$\begin{array}{llllll}99 \text { mT } & 1 & 2500 & 0.94 & 2659 & 99.96 \\ 990 \text { TC } & 2 & 3288.7 & 1.33 & 2472.7 & 99.96\end{array}$

$\begin{array}{llllrl}103_{\mathrm{Ru}} & 1 & 0.547 & 315.37 & 1.73 \times 10^{-3} & 0.17 \\ 103_{\mathrm{Ru}} & 2 & 0.962 & 142.80 & 6.74 \times 10^{-3} & 0.67 \\ 103_{\mathrm{Ru}} & 3 & 0.987 & 308.80 & 3.2 \times 10^{-3} & 0.32\end{array}$


Table 9. Distribution ccefficient of $99 \mathrm{mpc}$ and ${ }^{103_{R u}}$ for $2 \mathrm{~N} \mathrm{H}_{2} \mathrm{SO}_{4}$ - 5 NaClO extraction with a) Cyclohexanone and b) $58 \mathrm{TIOA} / \mathrm{xy}$ lene

Nuclides No. Org.phase Aqu.phase Distribution Extraction C.P.S. C.P.S. coefficient rate 8

a) Cyclohexanone - $2 \mathrm{~N} \mathrm{H}_{2} \mathrm{SO}_{4}-58 \mathrm{NaClO}$

$\begin{array}{llllll}99 \text { re } & 1 & 5411.12 & 50.13 & 107.9 & 99.08 \\ 99 \text { m re } & 2 & 381.84 & 6.06 & 63 & 98.49 \\ 99 \text { mre } & 3 & 441.08 & 1.09 & 404 & 99.80 \\ 99 \text { mrc } & 4 & 3271.95 & 65.65 & 49.8 & 98.0\end{array}$

$\begin{array}{llllll}103 \mathrm{Ru} & 1 & 236.63 & 10.30 & 22.98 & 95.82 \\ 103_{\mathrm{Ru}} & 2 & 260.45 & 7.25 & 35.9 & 97.3\end{array}$

b) 5 TIOA/xylene - $2 \mathrm{NH}_{2} \mathrm{SO}_{4}-5$ NaClO

$\begin{array}{llllll}99 \text { mpc }_{\text {Tc }} & 1 & 3996.46 & 40.18 & 99.5 & 99.0 \\ 99 \text { me }_{\text {Tc }} & 2 & 3769.63 & 43.92 & 85.8 & 98.8\end{array}$

$\begin{array}{llllll}103_{\mathrm{Ru}} & 1 & 240.12 & 79.09 & 3.04 & 75.2 \\ 103_{\mathrm{Ru}} & 2 & 232.69 & 79.11 & 2.94 & 74.6 \\ 103_{\mathrm{Ru}} & 3 & 247.16 & 81.55 & 3.03 & 75.2\end{array}$


Table 10. Determination of back-extraction rate 99mic from cyclohexanone with $\mathrm{H}_{2} \mathrm{O}$ and $0.5 \mathrm{~N} \mathrm{NaOB}$

Shaking time No. Org.phase Aqu.phase Back-extraction C.P.S. C.P.S. rate

a) With water from cyclohexanone

2 min.

2 min.

$$
1
$$

2

$$
2486
$$$$
1335
$$

1878

1919

43.0

59.0

5 min.

5 ain.
1

2

250.2

91.1

3664

93.6

3121

97.2

b) With $0.5 \mathrm{~N}$ NaOH from cyclohexanone

$\begin{array}{lllll}2 \text { min. } & 1 & 2.63 & 121.5 & 97.9 \\ 2 \text { min. } & 2 & 1.87 & 119.5 & 98.5\end{array}$

$\begin{array}{lllll}5 \text { min. } & 1 & 0.89 & 83.0 & 98.9 \\ 5 \text { min. } & 2 & 2.95 & 111.1 & 97.4\end{array}$

Table 11. Determination of back-extraction rate of 99ma from 58 TIOA/Xylene with $2 \mathrm{~N}$ NaOH

No. Org.phase Aqu.phase Back-extraction rate

C.P.S.

C.P.S.

$\begin{array}{llll}1 & 5.83 & 4077.2 & 99.86 \\ 2 & 4.29 & 3680.5 & 99.88\end{array}$


Table 12. Decontamination of ${ }^{103} \mathrm{Ru}, 110 \mathrm{mAg}$ and chemical yield of 99nrc of the procedure

Nucl. Before the procedure After the proc. Chem. Decontan. count C.P.S. count C.P.S. yield factor

$\begin{array}{lllrl}99 \text { me }_{\mathrm{re}} & 471.83 & 216.18 & 55.48 & \\ 103_{\mathrm{Ru}} & 215.5 & 0.0016 & 1.35 \times 10^{5} \\ 110 \mathrm{mAg} & 13.90 & 8.38 \times 10^{-5} & 1.66 \times 10^{5}\end{array}$


APPENDIX 2

\section{Purification of the ${ }^{99}$ Tc from electrodeposition plate}

1. Put the plate (which is deposited on the 99 $\mathrm{Tc}$ ) to a $25 \mathrm{ml}$ beaker. Add $0.2 \mathrm{ml} 1 \mathrm{~N}_{2} \mathrm{SC}_{4}$ to the plate. Add $1 \mathrm{ml} 58$ NaC10. The plate is covered by the solution. Stand $10 \mathrm{~min}$.

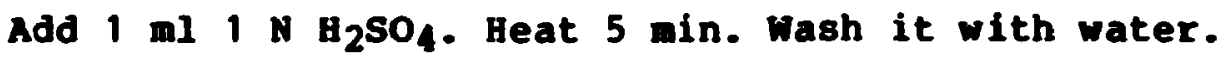

2. Transfer the plate to another $25 \mathrm{ml}$ beaker. Repeat step 1. Wash the plate three times with water. Combine these solutions.

(The following steps are required if more than several months have passed since the radioactivity was electrodeposited onto the plate. Add a few drops of concentrated $\mathrm{H}_{2} \mathrm{SO}_{4}$ to the plate. Stand a few min. Add a few drops $308 \mathrm{H}_{2} \mathrm{O}_{2}$ or $58 \mathrm{NaClO}$ to dissolve. Dilute the solution with water).

3. Add $0.5 \mathrm{ml} 5 \mathrm{mg} / \mathrm{ml} \mathrm{RuCl} 3$ carrier and $5 \mathrm{ml} 5 \%$ NaClo. Add $1 \mathrm{ml} \mathrm{AgNO}_{3} 10 \mathrm{mg} / \mathrm{ml}$. Heat $10 \mathrm{~min}$. Add $\mathrm{NaOH}$ to $\mathrm{pH}=12$. Heat the solution to get large precipitate. Pilter. Wash the precipitate with water.

4. Add $1 \mathrm{ml} 10 \mathrm{mg} / \mathrm{ml}$ AgNO$_{3}$. Heat the solution to get large precipitate. Filter. Wash the precipitate with water.

5. Add $1 \mathrm{ml} 5 \mathrm{~N} \mathrm{NaOH}$ to basic. Add $2 \mathrm{ml} 5 \mathrm{Nac} 10$. Heat $10 \mathrm{~min}$. Acidify to $\mathrm{pH}=4$ with $\mathrm{H}_{2} \mathrm{SO}_{4}$. Extract two times, each time with $20 \mathrm{ml} \mathrm{CCl}_{4}$. Discard the $\mathrm{CCl}_{4}$.

6. Add $1 \mathrm{ml} 5 \mathrm{~N} \mathrm{NaOH}$ and $2 \mathrm{ml} 58 \mathrm{NaClC}$. Heat $10 \mathrm{~min}$. Acidify to $\mathrm{pH}=4$ with $\mathrm{H}_{2} \mathrm{SO}_{4}$. Extract two timeh, each time with $20 \mathrm{ml}$ $\mathrm{CCl}_{4}$. Discard the $\mathrm{CC}_{4}$. 


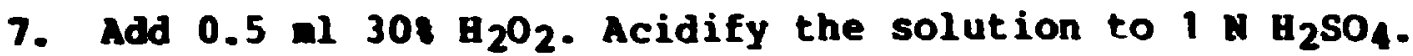
Bxtract with $20 \mathrm{ml} 58$ TIOA/xylene. Wash with $20 \mathrm{al} 1 \mathrm{~N} \mathrm{H}_{2} \mathrm{SO}_{4}$ containing af few drops $308 \mathrm{~B}_{2} \mathrm{O}_{2}$. Shake 1 min.

8. Back-extract two tines, each time with 20 ml 1 NaOH. Shake 1 min.

9. Evaporate to $20 \mathrm{ml} 2 \mathrm{~N}$ NaOH for electrodeposition. The current is $300 \mathrm{~mA}$. The tine is 3 to 5 hours.

10. The decontamination and chemical yield of the procedure are shown as follows:

Table 13.

Nucl. No. Before procedure After procedure Chem. Decontam. count C.P.S. count C.P.S. yield factor

$\begin{array}{llrcrl}99 \mathrm{mac} & 1 & 130.69 & 78.62 & 60.28 & \\ 99 \mathrm{me} & 2 & 89.88 & 55.86 & 62.18 & \\ 103_{\mathrm{Ru}} 1 & 74.74 & 2.62 \times 10^{-3} & 2.9 \times 10^{4} \\ 103_{\mathrm{Ru}} 2 & 53.18 & 2.13 \times 10^{-3} & 2.5 \times 10^{4} \\ 110 \mathrm{~m}_{\mathrm{Ag}} 1 & 12.29 & 2.29 \times 10^{-3} & 5.4 \times 10^{3} \\ 110 \mathrm{mAg} 2 & 9.01 & 1.68 \times 10^{-3} & 5.4 \times 10^{3}\end{array}$

11. Determination of the dissolution of $99 \mathrm{~m}$ Tc from electroposition plate. Compare the count between before and after the dissolved as follows:

No. Before the dissolution After the dissol. Left on the count C.P.S. count C.P.S. plate 8

$\begin{array}{llll}1 & 546.40 & 0.617 & 0.11 \\ 2 & 256.76 & 0.342 & 0.13 \\ 3 & 742.53 & 1.428 & 0.19 \\ 4 & 470.11 & 1.181 & 0.25\end{array}$


DETERMINATION OF TECHNETIUM-99 IN ENVIRONMENTAL SAMPLES BY SOLVENT EXTRACTION AT CONTROLLED VALENCE

Qingjiang Chen, A. Aarkrog, Helle Dick, Karen Mandrup

Project/contract no.

Abotrect (max. 2600 elhar.)

Distribution coefficients of technetium and ruthenium are determined under different conditions with $\mathrm{CCl}_{4}$, cyclohexanone, and $58 \mathrm{tri-iso-}$ octylamine TIOA/xylene. A method for analyzing ${ }^{99} \mathrm{Tc}$ in environmental samples has been developed by solvent extraction in which the valences of technetium and ruthenium are controlled with $\mathrm{H}_{2} \mathrm{O}_{2}$ and NaClO. Technetium and ruthenium which are oxidized to $\mathrm{TCO}_{4}^{-}$and $\mathrm{RuO}_{4}^{-}$ by NaClO are separated by extraction with $\mathrm{CCl}_{4}$ at $\mathrm{pH}=4$. The $\mathrm{RuO}_{4}^{-}$is reduced to low valence and technetium is kept in the $\mathrm{TcO}_{4}^{-}$state with $\mathrm{H}_{2} \mathrm{O}_{2}$. Technetium, ruthenium, and other nuclides are subsequently separated by solvent extraction with cyclohexanone and 58 TIOA/xylene. The decontamination of the procedure is $1.35 \times 10^{5}$ for ${ }^{103} \mathrm{ku}$ and $1.66 \times 10^{5}$ for ${ }^{110 m_{A g}}$. The chemical yield of technetium-99 is 558

Deseriplors - INIS

CARBON TETRACHLORIDE; DECONTAMINATION; HYDROGEN PEROXIDE; OXIDATION; RUTHENIUM COMPOUNDS; RUTHENIUM 103; SEAWATER; SOLVENT EXTRACTION; TECHNETATES; TECHNETIUM 99; TOA 
Avallable on request from.

Rise Library,

Rla National Laboratory, P. O. Box 48,

DK-4000 Roskllde, Denmark

ISBN 87.550- 1368.6

Phone (02) 371212 ext.2262

ISSN 0418-6435 